\title{
When does ISO 9000 lead to improvements?
}

\author{
Bozena Poksinska
}

\section{Linköping University Post Print}

\section{Tweet}

N.B.: When citing this work, cite the original article.

Original Publication:

Bozena Poksinska, When does ISO 9000 lead to improvements?, 2010, International Journal of Productivity and Quality Management, (5), 2, 124-136.

http://dx.doi.org/10.1504/IJPQM.2010.030738

Copyright: Inderscience

http://www.inderscience.com/

Postprint available at: Linköping University Electronic Press

http://urn.kb.se/resolve?urn=urn:nbn:se:liu:diva-44713 


\title{
When does ISO 9000 lead to improvements?
}

\author{
Bozena Poksinska, PhD \\ Quality Technology\& Management, Linköping University, \\ 58183 Linköping Sweden \\ Phone: +46 13282724 \\ Fax: +46 13281101 \\ Email: bozena.poksinska@liu.se
}

\begin{abstract}
The aim of this paper is to discuss and explain the conditions under which ISO 9000 is likely to have positive effects on organisational performance and employee development. The results described in this paper are coming from a research project looking at ISO 9000 in a more integrated manner using the different research strategies. Both questionnaire surveys and case studies investigating the processes related to ISO 9000 implementation and operation in the organisational settings were used. The value of ISO 9000 differs between organisations and depends on several organisational and external conditions, such as motivation for ISO 9000 implementation, maturity level of quality management, implementation strategy, certification audits, and involvement of people. For this reason benefits achieved from ISO 9000 are not the same for every organisation. They depend on the quality objectives set and the level of commitment to achieve business excellence.
\end{abstract}

Keywords: ISO 9001, Quality management systems, implementation processes, conditions for success, certification, audits

\section{Introduction}

The ISO 9000 series of standards was written to provide guidelines to assist organisations in implementing and operating a Quality Management System (QMS). With hundreds of thousands of certified companies around the world, ISO 9000 has become the most widely accepted and sought-after quality management system. Measured by market penetration, the ISO 9000 series has been a notable success.

The reasons behind the popularity of the standards are not really comprehensible. While there is considerable publication activity in the area, mainly on the implementation and benefits of the standards, the research community seldom asks explicitly why the management standards have been a success. 
The most logical answer to this question would be that companies choose the standards because of the many benefits they bring. However, from the beginning ISO 9000 generated contradictory opinions and assessments, and there was a general confusion and uncertainty regarding the effectiveness of the standard and its long-term contribution to the organisations (Douglas et al., 2003; Larsen and Häversjö, 2001; Stevenson and Barnes, 2001).

In fact, two different and to a large degree conflicting views have been revealed about the value of quality management systems (QMSs). The advocates of ISO 9000 claim substantial benefits from the system and often call it the entry key to TQM (Gotzamani and Tsiotras, 2001; Lee et al., 1999). They emphasise that ISO 9000 offers a shift in quality thinking from final inspection to more modern quality approaches such as process management, system approach, customer focus, and continual improvement. ISO 9000 is considered to be an effective tool for providing controls to ensure quality of production and delivery, and to reduce waste, downtime, and labour inefficiency (e.g. Casadesús and Karapetrovic, 2005a; Douglas et al., 2003; Gotzamani and Tsiotras, 2001; Han and Chen, 2007).

The opponents maintain that the standardisers have ignored the contemporary research on organisations and that the standard is based on management principles, which are out-of-date. The standard, for example, is driven by documentation and not organisational behaviour (Brunsson and Jacobsson, 2000). Furthermore, it is questioned if the standard is at all capable of improving the quality (Feng et al., 2008; Larsen and Häversjö, 2001; Sanders, 1994; Singels et al., 2001). Seddon (1997) called the standard an "economical disease" and stated that ISO 9000 encourages organisations to act in ways that make things worse for their customers, and is a step backward rather than forward.

This paper analyses and explains the conditions under which ISO 9000 is likely to have positive effects on organisational performance and employee development. Using the different research strategies and integrating the results from other related studies, this paper was able to provide a more comprehensive picture on ISO 9000 and to explain the partially contradictory results on the standards' effectiveness reported in the research.

\section{Literature review}

The wide acceptance of ISO 9000 has led to considerable interest in the research literature. Most of the previous studies investigated areas such as the motives for seeking certification, some implementation factors and benefits from the QMS (e.g. Carlsson and Carlsson, 1996; Casadesús and Karapetrovic, 2005b; Casadeus and Gimenez, 2000; Feng et al., 2008; Jang and Lin, 2008; Singels et al., 2001; Williams, 2004). Especially the research on the effects of implementing ISO 9000 series has been extensively reported. There are also many reviews of the literature in this area (e.g. Douglas et al., 2003; Oke and Charles-Owaba, 2007; Zeng et 
al., 2007). However, it would be interesting to review the literature in respect to the differences between the 1994 and the 2000 versions of ISO 9000 .

The ISO 9000:2000 series were greeted with mixed reactions because it was a total rewrite of the 1994 versions. However, the changes made in 2000 should have brought the standard more in line with the TQM principles. The revised version represented a real step forward in quality assurance, since it aimed at 'customer satisfaction assurance', not just product quality assurance. Furthermore, the 2000 standard changed its focus from product to process management, which was one of the main critics of the 1994 version. Another criticism addressed was that the old standards didn't require anything in the way of "real results". Under ISO 9001:2000 it isn't enough for an organisation just to have procedures and follow them, but it is also necessary to measure and improve organisational processes (Cochran, 2001; Conti, 1999; Laszlo, 2000). The new standard also produced new criticisms, such as that it is too general and not auditable (Russell, 2001) or that it is leaving its core competency and entering the crowded area of general management tools (Larsen and Häversjö, 2000).

The early studies on the effects of adopting ISO 9001:1994 span over a wide range of business performance indicators and frequently the results are contradictory. While some studies indicate only the marketing contribution (e.g. Buttle, 1997; Lloyds Register Quality Assurance, 1994; Quazi and Padibjo, 1998), others emphasise especially the improvements in the organisation (e.g. Brown et al., 1998; Rayner and Porter, 1991; Terziovski et al., 1997). The studies after 2000 provide more consistent results and at least some benefits of ISO 9000 implementation seem to be constant. These include decreasing nonconformities, enhanced quality, cost reduction, improved internal procedures and more effective communication (Casadesús and Karapetrovic, 2005b; Chow-Chua et al., 2003; Han and Chen, 2007; Quazi et al., 2002; Ruzevicius et al., 2004). Benefits such improved image and increased market share appear to be less significant as a second generation of ISO-certified organisations emerged (Feng et al., 2008). There is also considerable debate in the literature as to whether ISO 9000 has a positive impact both on operational and business performance. Terziovski et al. (2003) have indicated that while implementing the ISO 9000 standards led to improved operational performance, it did not give rise to better business performance. Corbett et al. (2005) clearly found a relationship between ISO 9000 certification and improved financial performance.

Van der Wiele et al. (2005) assessed the relative value of the ISO 9000:2000 standard in comparison with the 1994 version. One of the major findings of van der Wiele et al. (2005) were that there is an overall positive perception of the value of ISO 9000:2000 standards series and a consistently higher appreciation of the 2000 version compared with the 1994 version. Casadesus and Karapetrovic (2005) found that ISO 9001:2000 certified organisations perceive fewer benefits from the implementation than the ISO 9001-3:1994 certified 
organisations. The ISO 9001-3:1994 standards had a higher score on any particular benefit than ISO 9001:2000 had.

The literature on ISO 9000 contains considerable research that focuses on the respective impacts of motivations on ISO 9000 performance. Bothe the literature before and after ISO 9001:2000 is consistent with the conclusion that if the standard is internally driven organisations achieve higher overall benefits. In contrast, if the standard is implemented for some external motives like customer pressure the impact on performance will remain uncertain ( e.g. Boiral and Roy, 2007; Jones et al., 1997; Poksinska et al., 2002; Singels et al., 2001; Terziovski and Power, 2007; Tsiotras and Gotzamani, 1996). However, there is a lack of systematic empirical evidence investigating the implementation processes and all the conditions and factors influencing the ISO 9000 performance. The review of the literature indicates that ISO 9000 certification can deliver significant business benefits if it is implemented as part of a continuous improvement strategy (Terziovski and Power, 2007). The literature also points to the appropriate role of the quality auditor in facilitating this process (Poksinska et al., 2006a; Zeng et al., 2007).

\section{Methodology}

The results and reflections presented in this paper follow from five years research on ISO 9000. The research project consisted of three main stages: 1. survey on ISO 9000 and ISO 14000 implementation and operation, 2. case studies on ISO 9001:2000 certified companies and 3. survey of auditing practices. For an overview of the research designs and their relation to research questions see Table 1 .

Table 1. An overview of research designs

\begin{tabular}{|l|l|l|l|}
\hline & Description & Data collection & To investigate \\
\hline Stage 1 & $\begin{array}{l}\text { initial survey on } \\
\text { ISO 9000 and ISO } \\
14000\end{array}$ & postal questionnaire & $\begin{array}{l}\text { - motivation } \\
\text { - implementation factors } \\
\text { - benefits }\end{array}$ \\
\hline Stage 2 & $\begin{array}{l}\text { case studies on ISO } \\
\begin{array}{l}\text { companies } \\
\text { compon certified }\end{array}\end{array}$ & $\begin{array}{l}\text { - document studies } \\
\text { - questionnaire }\end{array}$ & $\begin{array}{l}\text { - practices of implementing } \\
\text { - conditions for and barriers to success } \\
\text { - influence on working conditions } \\
\text { - benefits }\end{array}$ \\
\hline Stage 3 & $\begin{array}{l}\text { survey on auditing } \\
\text { practices }\end{array}$ & postal questionnaire & $\begin{array}{l}\text { - auditing practices } \\
\text { - auditor' role } \\
\text { - benefits of auditing }\end{array}$ \\
\hline
\end{tabular}

\subsection{Stage 1: Initial survey on ISO 9000 and ISO 14000}

The questionnaire used in this stage was part of a global survey on ISO 9000 and ISO 14000 standards. The same survey was used to explore the state of ISO 9000 and ISO 14000 certification in the USA, Canada, Japan, Taiwan, Australia, France, Korea and Hong Kong. In 
each country, the survey was administered by local researchers. The same questionnaire form was used in all countries, translated by the local partner.

The questionnaire consisted of 16 questions about basic organisational data, motivation, benefits and implementation factors. Most questions were measured on a Likert scale with five points: 1 (very low), 2 (low), 3 (medium), 4 (high), 5 (very high).

The questionnaire form was sent to 268 companies all over Sweden at the end of October 2000. It was decided to choose every tenth certified company from a Swedish ISO $9000 / 14000$ database irrespective of its size, nature of business, certification date, etc. Of the 268 questionnaires mailed, 142 were returned by respondents, resulting in a response rate of $53 \%$. For more details of the survey methodology see Poksinska et al. (2002) and Poksinska et al. (2003).

\subsection{Stage 2: Case studies on ISO 9001:2000 certified companies}

The case study approach included three organizations where ISO 9001:2000 was implemented. The settings of the case study organizations are presented in Table 2.

Table 2. Settings of the case study organizations

\begin{tabular}{|l|l|l|c|l|}
\hline & \multicolumn{1}{|c|}{ Nature of business } & \multicolumn{1}{|c|}{$\begin{array}{c}\text { No. of } \\
\text { employees }\end{array}$} & Implementation & \multicolumn{1}{c|}{ Certification date } \\
\hline Case 1 & $\begin{array}{l}\text { Transforming and selling } \\
\text { by-products }\end{array}$ & ca. 45 & 1996 & 02.06 .05 \\
\hline Case 2 & $\begin{array}{l}\text { Manufacturing devices for a } \\
\text { cleaner production } \\
\text { environment }\end{array}$ & ca. 65 & 2000 & 02.01 .15 \\
\hline Case 3 & $\begin{array}{l}\text { Developing IT- and } \\
\text { communication systems }\end{array}$ & ca. 45 & 1995 & $\begin{array}{l}96.04 .01 \text { (ISO 9001:1994) } \\
02.01 .29 \text { (ISO 9001:2000) }\end{array}$ \\
\hline
\end{tabular}

In all three cases, the same process of data collection was applied. The methodological approach of the case studies was based on Porras and Robertson's model (Porras and Robertson, 1992), which was used as a framework for collecting and analyzing data. The aim of using this model in the data collection process was not to prove the causal relationship between the three sets of variables, but to structure and systematize the huge number of variables and contextual factors. The data collection methods included interviews, a questionnaire survey of all employees and document studies, and were organized in this way so they offered multiple data sources. More detailed description of the methodology of the case studies may be found in Poksinska (2006b).

\subsection{Stage 3: Survey on auditing practices}

The case studies were important in relation to the emergence of the new research questions. Several findings indicated that certification organisations may have a substantial role for the 
effectiveness of quality management systems. The decision was made to focus on studying certification organisations and the auditing process in the last stage of the project. Questionnaire survey was chosen as the research method.

The questionnaire consisted of 4 parts. The first part concerned the basic company data that means number of employees, ownership relationship, nature of business and customer category. The second part asked questions about the certification: data and scope of the certification, motives, main function of the QMS, certification body and reasons for the choice or change of an auditor, costs, auditor's role, satisfaction and perceived benefits from certification audits. The third part asked questions about how an audit process is performed: auditing time, number of auditors, sources of information, audit conclusions, differences between audit procedure for ISO 9001:2000 and ISO 9001-3:1994. The two final questions asked to give a general grade to auditors' work on the whole and to indicate in an open question other benefits besides the certificate. The fourth part asked in an open question to give comments on the questionnaire. Most questions were measured on a Likert scale with seven points where 1-is assigned to "strongly disagree" or "not at all" and 7- to "strongly agree" or "very much".

The questionnaire was sent to every tenth certified organisation in Sweden that means to 528 organisations in total. The final response rate was 51 percent. More information about the methodology of the survey may be obtained from Poksinska et al (2006a).

\section{Results}

A QMS designed according to ISO 9000 will differ considerably from organisation to organisation, because it is influenced by different organisational and external conditions. The most important organisational conditions are: maturity level of quality management, internal motivation, implementation strategy, involvement of people. The external conditions include certification audits and relationship with customers.

\subsection{Maturity level of quality management}

Organisations may have different maturity levels of quality management. For some organisations, ISO 9000 may mean a radical change; for others, it is just the usual way of running the business. When starting to implement the standard, organisations may to differing extents already comply with ISO 9001:2000 requirements. Seddon (1997), known for his critical view of ISO 9000, discusses Toyota in one of his arguments against the standard: "Toyota tried ISO 9000 in its Shimoyama factory in 2000 and promptly ceased its use for they found it to be of no value." Toyota is a company with a high maturity level of quality management and with an image of a strong quality organisation. If Toyota already complies with the requirements and doesn't need to strengthen its quality image with an ISO 9001:2000 
certificate, it is not surprising that the standard is of no value for the company. However, it doesn't mean that ISO 9000 is of no value for other organisations.

\subsection{Internal motivation}

This study showed that many organisations only certify to ISO 9000 because they are forced to by customers without reflecting on whether or not ISO 9000 is in fact appropriate to their business. Any improvement initiative needs a solid foundation to stand on. An improvement can only be accomplished through change, and without the proper motivation change will not happen (Pfeffer and Sutton, 2000). The internal motivation and design of ISO 9000 around the culture of the organisation is therefore the most important condition to achieve positive effects from the QMS. The design of the QMS has to start from the real needs of an organisation. The focus should not rest on fulfilling the minimum requirements, but on the areas that need to be improved. The objectives need to reflect the expectations of customers as well as the organisation's aims for future success. Therefore, only self-motivation will make improvement sustainable. If the ambition and commitment level are very low and organisations devote too much attention and place too much value on the certification, the focus on real improvements is shifted away by limiting the efforts to the satisfaction of the minimum necessary requirements, just fulfilling the auditors' demands and setting defensive and easy to achieve objectives.

\subsection{Implementation strategy}

Brunsson and Jacobsson (2000) discuss two strategies for implementing the standards. Organisations may standardise the practice or practise the standard. The first strategy implies that the practice is not changed, but only described in the language of the standard. The requirements of ISO 9001:2000 are general and there is considerable freedom in interpreting them. Organisations may interpret the requirements and the practice in such a way that they can claim that their existing processes already comply with the standard. Practicing standards implies that organisations reflect on a requirement and determine the best possible way of fulfilling it in the context of their organisation. Then the necessary changes in the practice are implemented. These implementation strategies are not alternatives that are totally free to choose, but rather should be fitted to the maturity level with quality management and to the improvement needs of the organisation. For mature companies it is in many cases just enough to standardise the practice to fulfil the ISO 9001:2000 requirements. However, there is not only one single way of fulfilling a requirement and things can always be done better. Organisations that represent a low level of quality management would be better off practising the standard. They should find a way to fulfil the requirements in the best possible way for the organisation. They should not confine themselves to the easiest way, but to the way that will 
provide value for the organisation. With this way of thinking, the QMS that is designed will likely have positive effects on organisational performance and employee development.

\subsection{Involvement of people}

Finally, an important organisational condition identified in this study was the involvement of people. Top management needs to show commitment and be involved in the quality work in order to demonstrate the importance of quality work to other employees. Without the continuous support and commitment from top management, the true importance of the initiative will be in doubt and the energy behind it will be weakened. A quality manager or other person with knowledge of quality management must work as facilitator and drive the improvement work. Finally, all employees need to know what the customer requirements are and be aware how their work contributes to their fulfilment. Everybody needs to be involved in tackling and solving the existing quality problems and identifying quality improvements. It will not only have positive results for organisational performance, but also for employee development. The opportunity to participate in the improvement work will make the employees feel important, valued, and aware that they can influence decisions important to their work. Both motivation for ISO 9000 implementation and the choice of the implementation strategy are important for people involvement. It will be difficult to cause people to feel motivated and involved if the motivation for ISO 9000 implementation is only exerted externally by customers. Furthermore, if an organisation, due to a lack of internal motivation, decides to fulfil only the minimum requirements and to standardise the practice, the quality work will mostly be associated with documentation and satisfying auditors' requirements. In such a situation employees perceive the QMS just as a system for handling documents, which decreases their enthusiasm to work actively with the system.

\subsection{Importance of certification audits}

There are almost no studies that look at certification audits as an important condition for achieving positive effects from ISO 9001:2000. This study showed that certification audits may be used as a tool for enhancing the effectiveness and continual improvement of the QMS. The process of third-party assessment was usually perceived as a routine exercise for obtaining ISO 9001-3 certification. Many organisations still don't recognize the opportunities for improvement that external auditing may provide to them. When the Swedish accreditation body introduced regulations for "man-days" used for auditing, some quality managers expressed concerns that they "will now have the police longer" in their organisations. This point of view is understandable if audits are perceived only as a checkpoint to be crossed in order to obtain the certificate, not as an opportunity to receive advice, new ideas, and help from outside. Longer audits can, however, only be positive, since that implies more time for 
getting into problems of audited organisations and consequently may lead to a better quality of audits.

As the auditing survey showed a development-oriented auditor may make valuable input to the QMS in the form of ideas and suggestions for improvement and the transfer of experience from other organisations. Audits also increase motivation and drive the quality work forward. If certification and periodic audits are performed with the aim of providing value for the audited organisation, not just issuing a certificate, this may have positive effects on operating the QMS and consequently on the effects from the system. But a documentation-oriented auditor checking just compliance with the ISO 9001:2000 requirements decreases the motivation and limits the efforts just to satisfying the auditors' demands (Poksinska et al., 2006a).

However, not only is a qualified and development-oriented auditor important, but also the audited organisations must be open to the opportunities certification audits may provide. The key is to understand that with ISO 9001:2000 an auditor is not a policeman, but more a facilitator.

\subsection{Relationship with customers}

The importance of the relationship with customers for the QMS was not fully explored in this project. However, one thing can be said. For the case organisations customer pressure was the primary driver to implement ISO 9000 and led them to focus on achieving the certificate. It seems reasonable to assume that the pressure exerted by customers to achieve an ISO 9001:2000 certificate is not the same for every organisation and the influence of customers on the QMS is different from organisation to organisation. One hopes that some customers focus more on the actual quality management practices themselves than on the certificate.

\subsection{Differences in benefits achieved}

There are many studies that have investigated the benefits from ISO 9000, but they provide partly contradictory results. This section aims to provide some possible explanations for why such contradictory results have been reported.

ISO 9000 requires organisations to establish procedures that, when followed, should ensure appropriate management of quality. However, the standard is very general and may be interpreted in many different ways. Since ISO 9000 can be implemented in many diverse business environments, the results are actually not comparable. The goals and objectives are set based on consensus within an organisation and may differ considerably from QMS to QMS. The primary drivers for setting objectives don't come from ISO 9000 itself, but are influenced by the organisation's position in the supply chain, market position, or simply the ambition to improve the organisation's performance. One organisation may achieve 
improvements in customer satisfaction because it defined such quality objectives and focused their efforts on customer complaints. Another organisation may reduce costs by focusing on poor quality costs. One of the most important results from the initial survey was that ISO 9000 is primarily implemented for external reasons and that the motivation influences the benefits. Many other studies came to similar conclusions (e.g. Boiral and Roy, 2007; Jones et al., 1997; Singels et al., 2001; Terziovski and Power, 2007; Tsiotras and Gotzamani, 1996).

In one of the case studies seven managers were asked to fill out a short questionnaire. The questionnaire consisted of 35 items describing different types of organisational performance indicators like product quality, customer satisfaction, customer returns, and productivity and the respondents were asked to assess the different performance improvements resulting from ISO 9000 implementation on a Likert scale with five points. The managers had difficulties in identifying the benefits resulting from operating ISO 9000 and often reported completely contradictory results. The problem was that the implementation of ISO 9000 didn't change many of the existing quality practices in the case organisation, because the organisation already complied with many of the ISO 9001:2000 requirements. The business continued as usual and the interviewed managers had difficulties seeing ISO 9000 as the cause of implementing any improvements. Only the quality manager, who perceived ISO 9000 as the current system used in the company for managing quality, recognized that some of the benefits stated in the questionnaire were achieved. Usually the benefits achieved from ISO 9000 are not regularly measured. At that moment, when a researcher asks for the information, the respondent has to decide what the effects are. Larsen and Häversjö (2001) consider that the effects might be socially constructed.

Taking into account the above considerations, the statement that there are benefits and that ISO 9000 provides value for the organisations sounds obvious. However, there is no unequivocal answer about what set of benefits organisations derive from ISO 9000 implementation.

\section{Conclusions}

The value of ISO 9000 differs among organisations and depends on several organisational and external conditions, such as motivation for ISO 9000 implementation, maturity level of quality management, implementation strategy, involvement of people, and certification audits.

ISO 9000 is still implemented mostly because of customer requirements and the certificate is the most desired outcome of implementing a quality management system. The certification to ISO 9001:2000 is a must in today's business environment. In fact, the certificate gives no competitive advantages, but gives a competitive disadvantage for organisations which are not certified. 
ISO 9000 offers organisations the capability to develop and implement an effective and dynamic quality management system with a focus on continual improvement, but the certification itself doesn't ensure that an organisation achieves sustained competitive advantages. The key to the success is the willingness and the depth to which an organisation desires to go in satisfying the standard's requirements or fulfilling their own improvement needs. However, organisations often lack internal motivation to work with the QMS. Those organisations devoting too much attention and placing too much value on the certificate would not be able to realise the full potential of ISO 9000 .

Organisations implementing ISO 9000 may have different maturity levels of quality management. The maturity level determines to what extent organisations can standardise the practice or practise the standard. However, ISO 9000 requirements are very general and organisations decide themselves what kind of practice complies with them. Consequently, organisations may claim that their organisational processes already comply with ISO 9000 without changing anything in their practice. Organisations lacking motivation to manage and improve their quality system limit their efforts to satisfying the minimum necessary requirements and only standardise the practice. For this reason, it is possible to become certified without changing anything in the organisation.

Furthermore, the involvement of people was identified as critical for the successful implementation and operation of a quality management system. Especially important is involvement of all employees in the quality work, which can be achieved through training and empowerment. Vital is also the commitment of top management and a dedicated and knowledgeable quality manager or facilitator.

Certification audits proved to be important for the effectiveness of the QMS. The auditing practices and the auditors' view on ISO 9000 may influence the way the QMS system is perceived and operated. Audits may provide valuable input to the improvement work and may be a motivating factor for continuous improvements. Some certification bodies progressed really far in the move from compliance audits to value-added management audits. Some are still only checking compliance with the standard's requirements.

The benefits achieved from ISO 9000 are not the same for every organisation. They depend on the level of ambition and commitment to achieve business excellence. There are only a few external and internal benefits that follow from the standard itself. Most internal benefits require a change in practice and commitment from all organisational members. 


\section{References}

Boiral, O. and Roy, M. (2007) 'ISO 9000: integration rationales and organizational impacts', International Journal of Operations \& Production Management, Vol. 27, No. 2, pp. 226-247.

Brown, A., van der Wiele, T. and Loughton, K. (1998) 'Smaller enterprises' experiences with ISO 9000', International Journal of Quality \& Reliability Management, Vol. 15, No. 3, pp. 273-285.

Brunsson, N. and Jacobsson, B. (2000) A World of Standards, Oxford University Press, New York.

Buttle, F. (1997) 'ISO 9000: marketing motivations and benefits', International Journal of Quality \& Reliability Management, Vol. 14, No. 9, pp. 936 - 947.

Carlsson, M. and Carlsson, D. (1996) 'Experiences of implementing ISO 9000 in Swedish industry', International Journal of Quality \& Reliability Management, Vol. 13, No. 7, pp. 36-47.

Casadesús, M. and Karapetrovic, S. (2005a) 'An empirical study of the benefits and costs of ISO 9001: 2000 compared to ISO 9001/2/3: 1994', Total Quality Management \& Business Excellence, Vol. 16, No. 1, pp. 105-120.

Casadesús, M. and Karapetrovic, S. (2005b) 'The erosion of ISO 9000 benefits: a temporal study', International Journal of Quality \& Reliability Management, Vol. 22, No. 2, pp. 120-136.

Casadeus, M. and Gimenez, G. (2000) 'The benefits of the implementation of the standard: empirical research in 288 Spanish companies', Total Quality Management, Vol. 12, No. 6, pp. 432-441.

Chow-Chua, C., Goh, M. and Wan, T. (2003) 'Does ISO 9000 certification improve business performance?' International Journal of Quality \& Reliability Management, Vol. 20, No. 8, pp. 936-953.

Cochran, C. (2001) 'The ISO to know', IIE Solutions, Vol. 33, No. 12, pp. 30-34.

Conti, T. (1999) 'Vision 2000: positioning the new ISO 9000 standards with respect to total quality management models', Total Quality Management, Vol. 10, No. 4/5, pp. 454464.

Corbett, C., Montes-Sancho, M. and Kirsch, D. (2005) 'The Financial Impact of ISO 9000 Certification in the US: An Empirical Analysis', Management Science, Vol. 51, No. 7, pp. 1046-1059.

Douglas, A., Coleman, S. and Oddy, R. (2003) 'The case for ISO 9000', The TQM Magazine, Vol. 15, No. 5, pp. 316-324.

Feng, M., Terziovski, M. and Samson, D. (2008) 'Relationship of ISO 9001: 2000 quality system certification with operational and business performance', Journal of Manufacturing Technology Management, Vol. 19, No. 1, pp. 22-37.

Gotzamani, K. D. and Tsiotras, G. D. (2001) 'An empirical study of the ISO 9000 standards' contribution towards total quality management', International Journal of Operations \& Production Management, Vol. 21, No. 10, pp. 1326-1342.

Han, S. B. and Chen, S. K. (2007) 'Effects of ISO 9000 on customer satisfaction', International Journal of Productivity and Quality Management, Vol. 2, No. 2, pp. 208-220.

Jang, W. and Lin, C. (2008) 'An integrated framework for ISO 9000 motivation, depth of ISO implementation and firm performance', Journal of Manufacturing Technology Management, Vol. 19, No. 2, pp. 194-216.

Jones, R., Arndt, G. and Kustin, R. (1997) 'ISO 9000 among Australian companies: impact of time and reasons for seeking certification on perceptions of benefits received', 
International Journal of Quality \& Reliability Management, Vol. 14, No. 6/7, pp. 650660.

Larsen, B. and Häversjö, T. (2000) 'The year 2000 problem of ISO 9000: will the quality standards survive the proposed year 2000 revision?' The TQM Magazine, Vol. 12, No. 4, pp. 226-237.

Larsen, B. and Häversjö, T. (2001) 'Management by standards - real benefits from fashion', Scandinavian Journal of Management, Vol. 17, No. 4, pp. 457-480.

Laszlo, G. P. (2000) 'ISO 9000 - 2000 version: implications for applicants and examiners', The TQM Magazine, Vol. 12, No. 5, pp. 336-339.

Lee, T., Leung, H. and Chan, K. (1999) 'Improving quality management on the basis of ISO 9000', The TQM Magazine, Vol. 11, No. 2, pp. 88-94.

Lloyds Register Quality Assurance (1994) BS 5750/ ISO 9000 - Setting Standards for Better Business, Lloyds Register Quality Assurance Services Ltd.

Oke, S. A. and Charles-Owaba, O. E. (2007) 'Implementation of ISO-based quality management systems: a review of the literature', International Journal of Productivity and Quality Management, Vol. 2, No. 1, pp. 81-111.

Pfeffer, J. and Sutton, R. I. (2000) The Knowing-Doing Gap: How Smart Companies Turn Knowledge Into Action, Harvard Business School Press, Boston.

Poksinska, B., Dahlgaard, J. J. and Antoni, M. (2002) 'The State of ISO 9000 Certification - A Study of Swedish Organizations', The TQM Magazine, Vol. 14, No. 5, pp. 297-306.

Poksinska, B., Dahlgaard, J. J. and Eklund, J. (2003) 'Implementing ISO 14000 in Sweden: Motives, Benefits and Comparisons with ISO 9000', International Journal of Quality \& Reliability Management, Vol. 20, No. 5, pp. 585-606.

Poksinska, B., Dahlgaard, J. J. and Eklund, J. A. E. (2006a) 'From Compliance to ValueAdded Auditing - Experiences from Swedish ISO 9001:2000 certified organisations', Total Quality Management \& Business Excellence, Vol. 17, No. 7, pp. 879-892.

Poksinska, B., Eklund, J. A. E. and Dahlgaard, J. J. (2006b) 'ISO 9001:2000 in Small Organisations - Lost Opportunities, Benefits and Influencing Factors', International Journal of Quality \& Reliability Management, Vol. 23, No. 5, pp. 490-512.

Porras, J. I. and Robertson, P. J. (1992) In Handbook of industrial and organizational psychology, Vol. 3, Eds. Dunnette, M. D. and Hough, L. M., CA: Consulting Psychologists Press, Palo Alto, pp. 719-822.

Quazi, H., Hong, C. and Meng, C. (2002) 'Impact of ISO 9000 certification on quality management practices: A comparative study', Total Quality Management, Vol. 13, No. 1, pp. 53-67.

Quazi, H. A. and Padibjo, S. R. (1998) 'A journey toward total quality management through ISO 9000 certification - a study on small- and medium-sized enterprises in Singapore', International Journal of Quality \& Reliability Management, Vol. 15, No. 5, pp. 489508.

Rayner, P. and Porter, I. J. (1991) 'BS 5759/ISO 9000 - the experience of small and medium sized firms', International Journal of Quality \& Reliability Management, Vol. 8, No. 6, pp. 16-28.

Russell, J. P. (2001) Auditing ISO 9001:2000, Quality Progress, Vol. 34, pp. 147-148.

Ruzevicius, J., Adomaitiene, R. and Sirvidaite, J. (2004) 'Motivation and Efficiency of Quality Management Systems Implementation: a Study of Lithuanian Organizations', Total Quality Management \& Business Excellence, Vol. 15, No. 2, pp. 173-189.

Sanders, R. (1994) 'Will ISO 9000 improve my records management program?' Records Management Quarterly, Vol. 28, No. 4, pp. 47-53.

Seddon, J. (1997) 'Ten arguments against ISO 9000', Managing Service Quality, Vol. 7, No. 4, pp. 162-168. 
Singels, J., Ruel, G. and Water, H. v. d. (2001) 'ISO 9000 series - Certification and performance', International Journal of Quality \& Reliability Management, Vol. 18, No. 1, pp. 62-75.

Stevenson, T. and Barnes, F. (2001) 'Fourteen years of ISO 9000: impact, criticisms, costs, and benefits', Business Horizons, Vol. 44, No. 3, pp. 45-51.

Terziovski, M., D., S. and Dow, D. (1997) 'The business value of quality management systems certification: evidence from Australia and New Zealand', Journal of Operations Management, Vol. 15, No. 1, pp. 1-18.

Terziovski, M. and Power, D. (2007) 'Increasing ISO 9000 certification benefits: a continuous improvement approach', International Journal of Quality \& Reliability Management, Vol. 24, No. 2, pp. 141-163.

Tsiotras, G. D. and Gotzamani, K. D. (1996) 'ISO 9000 as an entry key to TQM: the case of Greek industry', International Journal of Quality \& Reliability Management, Vol. 13, No. 4, pp. 64-76.

Williams, J. (2004) 'The impact of motivating factors on implementation of ISO 9001: 2000 registration process', Management Research News, Vol. 27, No. 1, pp. 74-84.

Zeng, S., Tian, P. and Tam, C. (2007) 'Overcoming barriers to sustainable implementation of the ISO 9001 system', Managerial Auditing Journal, Vol. 22, No. 3, pp. 244-254. 